\title{
Soyada Bitki Besleme ve Hastalıklarla Mücadele Yöntemi Olarak Yapraktan Mangan Uygulamaları
}

Effect of Foliar Manganese Applications on Yield Quality and Diseases Progresses of Soybean

Uğur SEVILIMIŞ̧ ${ }^{1}$

Deniz SEVILLMIŞ̧ ${ }^{2}$

Yaşar Ahu ÖLMEZ ${ }^{2}$

Sait AYKANAT ${ }^{1}$

Oktay Burak ÖZCAN²

${ }^{1}$ Doğu Akdeniz Tarımsal Araştırma Enstitüsü Müdürlüğü, Adana

${ }^{2}$ Yağlı Tohumlar Araştırma Enstitüsü, Osmaniye

*Sorumlu yazar: sevilmisugur@yahoo.com

\section{ORCID (Yazar Sırasına Göre):}

iD 0000-0003-3030-3160

(iD) $0000-0003-3030-3160$

(iD) $0000-0003-1922-1228$

(iD) $0000-0002-5690-408 \mathrm{X}$

(iD) $0000-0001-8438-7932$

Gönderilme Tarihi : 16 Ocak 2020

Kabul Tarihi

: 23 Mart 2020

\section{Özet}

Mangan bitkilerde esas olarak fotosentez, lipid biyosentezi ve oksidatif stres ile ilişkili temel metabolik işlemlerde kofaktör olarak görev yapmaktadır. Mn eksikliği bitkilerde büyüme ve verim azalırken patojenlere ve don hasarına karşı hassasiyet artmaktadır. Mangan noksanlığının sık görüldüğü kireçli, yüksek pH'ya sahip topraklara mangan sülfat gibi tuzlar vermek genellikle faydasız bulunmaktadır. Çünkü verilen mangan kısa sürede yükseltgenerek alınamaz forma dönüşmektedir. Ayrıca topraktaki Mn, aynı yerde bir yetiştirme sezonu boyunca hem eksik hem de toksik olabilen tek elementtir. Bu durumun sebebi olarak toprağın sulama gibi sebeplerle su altında kalması, mikrobiyal faaliyetleri ve hacim ağırlığının manganın etkinliğini ciddi şekilde etkilemesidir.

Türkiye'nin soya üretiminde kendine yeterliliğinin çok düşük bir düzeyde olması, soya üretiminin artırılmasını zorunlu kılmaktadır. Türkiye'de soya ekim alanlarının büyük kısmının bulunduğu Çukurova Bölgesi'nde toprakların Mn düzeyi düşük durumdadır. Soya bitkisi Mn eksikliğine karş1 oldukça hassastır ve soyada mangan eksikliği diğer mikro besin eksikliklerinden daha sık görülür fakat soya, eksiklik durumunda Mn gübrelerine iyi yanıt verir. Mangan eksikliği, 
yüksek pH'ya sahip topraklarda yetiştirilen soyada tekrarlayan bir sorundur. Kimyasal gübrelerin topraktan uygulanması bu eksiklikten kaynaklanan verim kayıplarını hafifletmek için kullanılmaktadır ancak çoğu zaman etkisiz kalmaktadır. $\mathrm{Bu}$ derlemede soyada yapraktan mangan uygulamaları konusunda dünyada yürütülmüş bitki besleme çalışmalarının yanında manganın, yeni bir alan olan fungusit olarak kullanımı konusunda yapılmış çalışmalar da bir araya getirilmiş ve değerlendirilmiştir.

Anahtar Kelimeler: Soya, mangan, yapraktan uygulama, verim, kalite, hastalık

\section{Abstract}

In plants, manganese mainly acts as a cofactor in relation to basic metabolic processes such as photosynthesis, lipid biosynthesis and oxidative stress. Growth and yield decreases and sensitivity to pathogens and frost damage increases when Mn get deficient in plants. Giving salts such as manganese sulphate to calcareous, high $\mathrm{pH}$ soils where manganese deficiency is common is generally assumed to be useless due to fast oxidization of the applied manganese and convertion it i soil into unavailable form for plants to absorb. Furthermore, Mn in soils is the only element that can be both deficient and toxic throughout a growing season in the same location. Reason for this is the adverse affects of flooding due to irrigation, microbial activities and volume weight of soils on the efficiency of manganese. Soybean plant is very sensitive to Mn deficiency and manganese deficiency in soybean is more frequent than other micronutrient deficiencies but responce to Mn fertilizers is well when it is deficient.

Very low soybean production self sufficiency levels of Turkey creates a force to increase production of soybean. In Cukurova region, where the majority of the soybean acreage in Turkey locates, Mn levels in soils are low. Soybean plant is very sensitive to Mn deficiency and manganese deficiency in soybean is more common than other micronutrient deficiencies but responce of this crop to Mn fertilizers is good in case of deficiency. Manganese deficiency is a recurrent problem in soybean grown on soils with high $\mathrm{pH}$. The application of chemical fertilizers from the soil is used to alleviate yield losses due to this deficiency, but is often ineffective. In this review, in addition to the foliar manganese nutritioning studies carried out in the World, the studies on the usage of manganese as a fungicide as a new study field were assembled and evaluated for soybean crop.

Keywords: Soybean, manganese, foliar application, yield, diseases

\section{1-Giriş}

Mangan (Mn, manganez) bitki büyümesinde temel bir elementtir (Izaguirre-Mayoral ve Sinclair, 2005).Bitkilerde birçok biyokimyasal işlemde rol oynar ki esas olarak fotosentez, lipid biyosentezi ve oksidatif stres gibi temel işlemlerde kofaktör olarak görev yapar (Socha ve Guerinot, 2014). Bununla birlikte, enzimlerin yapısal bileşenleri olan $\mathrm{Cu}, \mathrm{Zn}, \mathrm{Fe}$ ve Mo gibi diğer iz elementlerin aksine Mn genellikle bir enzim aktivatörüdür ve başka metal iyonları ile değiştirilebilir durumdadır. Mn'nin biyokimyasal işlevi $\mathrm{Mg}$ ’ye benzer ve enzimleri katalizlediği reaksiyonlar (fosforilasyon, dekarboksilasyon, 
indirgeme ve hidroliz) yanında solunum, amino asit sentezi, lignin biyosentezi ve bitkilerdeki hormon seviyesini aktive etme işlevlerini yürütür (Burnell, 1988).

Tarla bitkileri, çayır-mera bitkileri ve ağaçların verimi, Mn eksikliğinden veya fazlalığından (toksisite) olumsuz etkilenir (Campbell ve Nable, 1988). Mn eksikliği olan bitkilerde büyüme ve verim azalırken patojenlere ve don hasarına karşı hassaslaşma ortaya çıkar. Mn eksikliği, en çok alkali topraklarda öne çıkar ki dünyada toprakların yaklaşık üçte biri optimum tarımsal üretim için fazla alkalidir (Socha ve Guerinot, 2014). Mn, topraklarda Mn(II), Mn(III) ve Mn(IV) şeklinde farklı redoks formlarında bulunur ki $\mathrm{Mn}(\mathrm{II})\left(\mathrm{Mn}^{2+}\right.$ şeklinde) bitkiler için en uygun Mn formudur (Johansson, 2005).

Bitkilerde mangan noksanlığ Mg noksanlığ 1 belirtilerine benzer. Yapraklarda damarlar arasında sararma görülür. Ancak Mg noksanlığı önce yaşlı yapraklarda görülmesine karşın Mn noksanlığı genç yapraklarda görülür. Mangan noksanlığında, yapraklar arası kloroza ilave olarak yapraklarda sarı noktalar halinde lekeler de oluşur. Yaprak analizleri doğru teşhis için önemli bir araçtır ki yaprakta 25-30 ppm'den düşük olması durumunda bitkide mangan eksikliği muhtemeldir (Sönmez ve ark., 2018). Mangan noksanlığının sık görüldüğü kireçli, yüksek pH'ya sahip topraklara mangan sülfat gibi tuzlar vermek genellikle faydasızdır. Çünkü verilen mangan kısa sürede yükseltgenerek alınamaz forma dönüşür. Dekara 10-50 g Mn düşecek şekilde şelatlı gübreler yapraklardan uygulanabilir. Manganın bitkilerde hareketi iyi olmadığından uygulama 2-3 kez tekrarlanmalıdır (Sönmez ve ark., 2018).

Mn toksisite belirtileri ise genel olarak $\mathrm{Mn}$ eksiklik belirtilerine benzer. $\mathrm{Bu}$ element tarafından faaliyete geçirilen enzim sistemlerinde yüksek $\mathrm{O}_{2}$ alımı ve denge kaybı durumları $\mathrm{Mn}$ toksisitesi ile ilişkilendirilmiştir. Mangan; $\mathrm{Ca}$, $\mathrm{Fe}, \mathrm{Cu}, \mathrm{Al}, \mathrm{Si}, \mathrm{Mg}, \mathrm{K}, \mathrm{P}$ ve $\mathrm{N}$ de dahil olmak üzere bazı temel elementlerin alım, taşınım ve kullanımına da müdahil olur. Toprakların yüksek mikrobiyal aktivitesi, su tutması ve kötü yapıya sahip olmas1, nötr topraklarda bile şiddetli Mn toksisitesine neden olabilir (Mukhopadhyay ve Sharma, 1991). $\mathrm{Mn}^{2+}, \mathrm{Mg}^{2+}$ ile etkin bir şekilde rekabet eder ve alımını kuvvetli bir şekilde azaltır. (Mukhopadhyay ve Sharma, 1991).

Mn fitotoksisitesi, biyokütle ve fotosentezin azalması ve oksidatif stres gibi biyokimyasal bozukluklarla kendini gösterir. Hücrelerin içinde bulunduğunda, sürgünler ve yaprak hücrelerinin bölümlerinde hapsetme gibi toksisiteyi azaltan mekanizmalar da gözlenebilir (Millaleo ve ark., 2010). Mn birikimi bitkilerde özellikle yaprak sap1, palisade ve süngerimsi parankimi hücrelerinin periferik hücrelerinde gerçekleşir (Mukhopadhyay ve Sharma, 1991).

Türkiye üst $(0-30 \mathrm{~cm})$ tarım topraklarının verimlilik durumunu yansitacak olan bazı toprak özellikleri, makro-mikro bitki besin elementleri ve toprak organik karbon içeriğinin coğrafi veritabanını oluşturmayı amaçlayan bir TAGEM projesi 2018 yılında tamamlanmıştır. "Türkiye Topraklarının Bazı Verimlilik ve Organik Karbon (TOK) İçeriğinin Coğrafi Veritabanının 
Oluşturulması" isimli proje kapsamında Türkiye'nin tüm bölgelerinden alınan 7758 adet toprak örneğinde bazı toprak verimlilik analizleri ile bazı toprak fiziksel analizleri yapılmıştır. $\mathrm{Bu}$ çalışmada, Türkiye topraklarının alınabilir mangan (Mn) içeriğinin ortalama olarak 18,29 ppm olduğu belirlenmiştir (Sönmez ve ark., 2018) (Şekil 1 ve Çizelge 1).

Soya (Glycine max (L.) Merril), insan g1dası ve biyoyakıt hammaddesi olarak değerli olan yağı ve hayvansal yetiştiricilik için yüksek ve nitelikli protein içeriği nedeniyle dünyadaki en değerli tarımsal ürünlerden biridir (Masuda ve Goldsmith, 2009). Türkiye'de üretilen soyanın önemli bir kısmı Çukurova Bölgesi’nde bulunan Adana ve Mersin illerinde yetiştirilmektedir. Her ne kadar bu bölgede verim düzeyleri yüksek olsa da Türkiye'nin soya üretim miktarı çok düşüktür. Örneğin 2017 yılında soyada ülkesel kendine yeterlik düzeyimiz \%4,8 düzeyinde olmuştur (TÜİK, 2018). Bu durum ülkesel soya üretiminin artırılmasını zorunlu kılmaktadır. Bu nedenle soyada verim kisitlayıcı potansiyel problemlerin detaylı araştırılması önem arz etmektedir. Türkiye topraklarının Mn düzeyi haritasından görüleceği üzere, Türkiye'de soya ekim alanlarının büyük kısmının bulunduğu Çukurova Bölgesi'nde toprakların Mn düzeyi düşük durumdadır (Şekil 1).

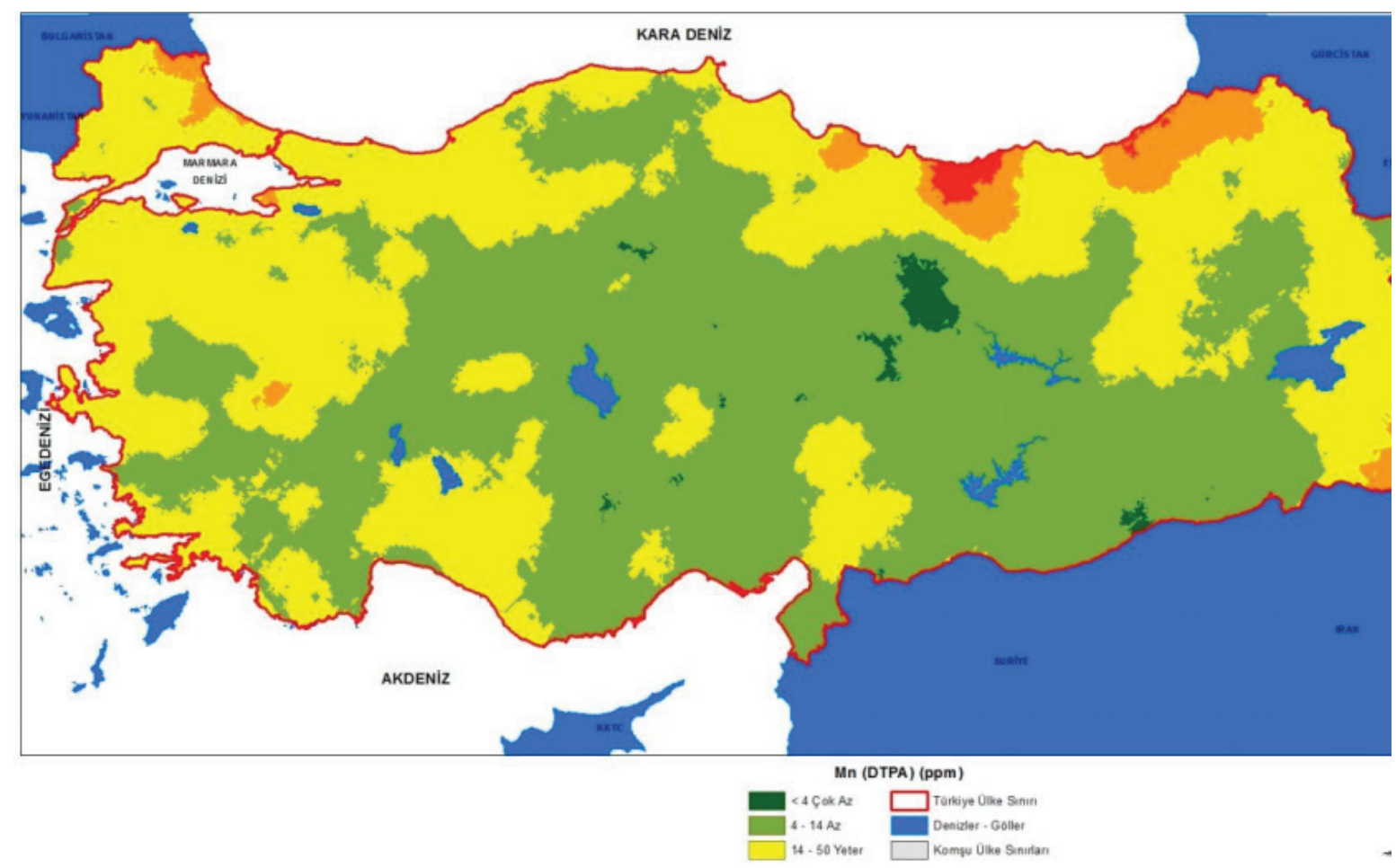

Şekil 1. Türkiye topraklarının mangan $(\mathrm{Mn})$ haritası (Sarı=Yeter, Açık yeşil=Az, Koyu Yeşil=Çok az, Turuncu=Fazla, Kırmızı=Çok fazla) (Sönmez ve ark., 2018) 
Çizelge 1. Türkiye topraklarının mangan (Mn) içeriği dağılımı (Sönmez ve ark., 2018)

\begin{tabular}{|l|l|}
\hline Topraktaki Mn Miktarı (DTPA) (ppm) & Alan (milyon ha) \\
\hline Çok az $(<4)$ & 0,6 \\
Az $(4-14)$ & 41,6 \\
Yeter $(14-50)$ & 32,2 \\
Fazla $(50-170)$ & 3,1 \\
Çok fazla $(>170)$ & 0,3 \\
\hline
\end{tabular}

\section{2-Soyada Mn Eksikliği}

Soya bitkisinde mangan eksikliği tohum verimini azaltıp yă̆ içeriğinin profilini değiştirmektedir (Alt ve ark., 2018). Soya çeşitlerinin de Mn eksikliği ve toksisitesine karşı tepkileri değişkendir (Ohki, 1981). Ghazali ve Cox, (1981), soyada mangan eksikliğinin yaz mevsimine kıyasla ilkbaharda daha fazla görüldüğünü göstermiştir. $\mathrm{Bu}$ durumun, artan büyümeye karşı Mn arzında görülen düşüş veya daha soğuk koşullar altında Mn ihtiyacındaki bir artıştan kaynaklanıyor olabileceğini bildirmiştir.

Soya bitkisi Mn eksikliğine karşı oldukça hassastır (Mascagni ve Cox, 1985). Soyada mangan eksikliği diğer mikro besinlerden daha sık görülür ve eksiklik durumunda soya, Mn gübrelemesine iyi yanıt verir. Manganın kumlu topraklarda, kuru topraklarda, yüksek organik madde içeren topraklarda ve yüksek $\mathrm{pH}$ seviyesine sahip topraklarda eksik olması daha olasıdır (Diedrick, 2010). Mangan eksikliği, yüksek pH'ya sahip topraklarda yetiştirilen soyada tekrarlayan bir sorundur. Kimyasal gübrelerin topraktan uygulanması bu eksiklikten kaynaklanan verim kayılarını hafifletmek için kullanılmaktadır fakat çoğu zaman etkisiz kalmaktadır (Graham ve ark., 1995).

Wilson ve ark., (1982), ciddi Mn eksikliğinin (yapraklarda 15 ppm Mn'den az), soyada tohumda ki proteini oranını artırdığını, tohum yağ oranını ise düşürdüğünü tespit etmiştir. Son derece düşük yaprak Mn seviyesine sahip bitkilerden elde ettikleri tohumların oleik asit oranı da düşük bulunmuştur.

Soyada biyolojik azot bağlama sonrası nodüllerden bitkinin üst aksamlarına taşınan ana ürün olan ureidlerin yapraklarda katabolizması için Mn bir kofaktör durumundadır. Soya bitkileri Mn açısından eksik besin çözeltilerinde yetiştirildiğinde ureid katabolizma oranında genotipe özgü farklılıklar gözlenmektedir (Izaguirre-Mayoral ve Sinclair, 2005).Soyada su stresi de sürgünlerde N2 fiksasyon ürünlerinin (ureides) birikmesine neden olmaktadır ve bu, $\mathrm{N}_{2}$ fiksasyonunun engellenmesine yol açmaktadır. Mangan, yapraklarda ureide yıkımı için gereklidir. Artan yaprak $\mathrm{Mn}^{+2}$ konsantrasyonu ureid yıkımını arttırmakta ve kısıtlı su koşulları altında biyolojik $\mathrm{N}_{2}$ bağlama tepkimesini iyileştirmektedir (Purcell ve ark., 2000). 
Yürütülmüş bir çalışmada soya bitkisinde karbonik anhidraz aktivitesi, şiddetli Mn eksikliğine bağlı olarak 3 kat artmıştır (Ohki, 1981).

Manganca eksik bir besin çözeltisiyle perlit içinde yetiştirilen soya bitkileri, tipik olarak yapraklarda damararası kloroz ve nekroz belirtileri göstermiştir. Eksiklik gösteren bitkilerde fotosentetik oran, kuru yaprak ağırlığ1, yaprak alanı, klorofil içeriği ve kloroplast sayısında bir azalma gözlenmiştir. Mn eksikliği olan yaprak dokusunun transmisyon elektron mikroskopisi gözlemleri, kloroplast lamellar ağında düzensizleşme, homojen olmayan stroma dağılımı ve çimlenmeden 28 gün sonra bitkilerde nişasta miktarlarında bir azalma olduğunu ortaya koymuştur. Veriler, manganın hem fotosentetik aparatta bir gereklilik hem de lamel zardaki yapısal bir bileşen olarak işlev gördüğünü göstermiştir (Weiland ve ark., 1975).

$\mathrm{Mn}, \mathrm{Zn}, \mathrm{Cu}$ ve $\mathrm{Fe}$ eksikliğinin erken görsel semptomlarının yorumlanması genellikle zordur ve yanlış teşhisler yaygındır (Adams ve ark., 2000).

Mn eksikliğini teşhis için yapraktaki Mn konsantrasyonu ölçümleri yapılabilir. Bitki analizlerinin etkili olması için, doğru büyüme aşamalarında yapılması gereklidir. Mascagni ve Cox, (1985), tarla koşullarında soya bitkisi ile 38 deneme x yıl kombinasyonuna sahip bir çalışma yapmıştır. Verimin tepkisini tahmin etmede kullanmak amacıyla yapılacak bitki örneklemesi için en uygun dönemin R2 büyüme aşaması olduğu belirlemiştir. Kritik Mn konsantrasyonu, bu dönemde 17 ila 22 mg kg-1 arasında değişim göstermiştir. R2 aşamasından önce örnekleme yapmayı daha az güvenilir bulmuştur. Diedrick, (2010) da bitki dokusu analizini, mangan eksikliğini doğrulamak için en iyi araç olduğunu bildirmiştir.

ABD'deki Mn eksikliği bulunan Atlantic Kıyı Ovaları topraklarında tüm bitki, yaprak ve tohum için kritik Mn eksikliği seviyelerini belirlemek amacıyla bir tarla araştırması yapılmıştır. Soya denemeleri, 7 yıl süresince ve 13 toprak tipinde 30 yerde gerçekleştirilmiştir ve 8 soya çeşidi kullanılmıştır. Tüm bitki, yaprak ve tohum için kritik Mn seviyeleri sırasıyla 45, 17 ve $20 \mathrm{mg} \mathrm{kg}^{-1}$ bulunmuştur (Gettier ve ark., 1985a).

Adams ve ark., (2000), 1şık yansitma ve floresans ölçümlerinin $\mathrm{Mn}, \mathrm{Zn}, \mathrm{Cu}$ ve $\mathrm{Fe}$ eksikliklerinin erken ve daha güvenilir tespiti için uygunluğunu test etmişlerdir. $\mathrm{Mn}, \mathrm{Zn}, \mathrm{Cu}$ ve Fe eksikliklerini sirasiyla \%62, 40, 92 ve 30 oranında doğru olarak tespit etmişlerdir. Doku analizinde eksik besin elementi içeriğine sahip olduğu tespit edilen yaprakların üçte biri ile yarısının görsel belirtiler göstermediğini bildirmişlerdir.

Soyada yaşlı yapraklardaki Mn konsantrasyonu, genç olanlardan daha yüksektir. Mn mobilitesi, yaprak Mn seviyesine bağlı olarak değişir. Yaprak Mn konsantrasyonları düşük olduğunda Mn hareketsizdir, ancak yapraklarda Mn seviyesi yüksek olduğunda bir miktarı taşınmaktadır. Toprağı su basması durumunda, soyada yeni gelişen ve yaşlı yapraklarda Mn seviyesini hizla artırmakta, fakat toprağın kuruması sonrası genç yapraklardaki 
Mn konsantrasyonu düşerken yaşlı yapraklarda su basması sırasındaki anaerobik koşullar altında biriktirilmiş $\mathrm{Mn}$ seviyesi korunmaya devam etmektedir. Bu nedenle, en üstteki olgun üç yaprak, toprağının Mn durumunun tespiti için yapılacak kimyasal analizde kullanmak amacıyla örneklenmesi için bitkinin uygun bir parçasıdır (Kluthcouski ve Nelson, 1979). Yürütülen bir çalışmada, soya bitkisinde üstteki üçüncü yapraktaki Mn konsantrasyonu, büyümenin tüm aşamalarındaki diğer kısımlardan daha yüksek bulunmuştur (Singh ve Banerjee, 1984).

\section{Soyada Yapraktan Mangan Uygulamaları}

Manganın, bitkilerce topraktan alımında önemli rol oynayan karmaşık bir redoks kimyası vardır. $\mathrm{Bu}$ nedenle yetiştirme sezonu boyunca aynı yerde hem eksik hem de toksik olabilen tek elementtir. Toprağın su içeriği, bitkide bulunan Mn miktarı ile korelasyon halindedir. Ayrıca Mn çözünürlüğü, kütle yoğunluğu yüksek topraklarda daha yüksektir. $\mathrm{Bu}$ muhtemelen yüksek kütle yoğunluklarında daha hızlı oksijen tükenmesinin bir sonucudur (Johansson, 2005). Aşırı Mn’a maruz kalan soya bitkileri, $\mathrm{CO}_{2}$ asimilasyon oranı ve stoma iletkenliğinde düşüşler göstermektedir ki bu da, toprak üstü biyokütlenin azalmasına neden olmaktadır (Santos ve ark., 2017).

Köklerden emilim ve taşınım işlemlerinde Zn ve Mn arasındaki etkileşimler gerçekleşir (Reddy ve ark., 1978). Demir eksikliği durumunda topraktan Fe-EDDHA gübrelerinin uygulanması eksikliğinin düzeltilmesinde etkilidir, ancak bu uygulama Mn de dahil olmak üzere bazı mikro besin maddelerinin konsantrasyonunu ve alımını azaltabilir (Ghasemi $\square$ Fasaei ve ark., 2002).

Zhang, (2005), manganın soya verimi üzerine etkisini tohum muamelesi ve yaprağa püskürtme denemeleriyle karşılaştırmalı şekilde tespit etmek amacıyla bir çalışma yürütülmüştür. Kullandığı her iki soya çeşidinde de Mn uygulanması, bitki başına tohum sayısını, bitki başına bakla sayısını, bitki boyunu ve 100 tohum ağırlığını hem tohum kaplama hem de yaprağa püskürtme uygulaması ile arttırmıştır.

Yapraktan Mn uygulamaları için genelde mangan sülfat tercih edilmektedir (Heckman ve ark., 1999). Mederski ve Hoff, (1958), soya bitkilerinde $\mathrm{Mn}$ konsantrasyonun, bitki yüzeyi ile tatbik edilen mangan sülfat çözeltisinin temasından 15 dakika sonra 200 ppm yükseldiğini tespit etmiştir. Yapraklar ve saplar tarafindan emilen Mn miktarı, uygulanan çözeltinin Mn konsantrasyonu, bitki sıcaklığı ve manganın yaprak yüzeyinde çözelti halinde kaldığı süre arttıkça arttığını bildirmiştir.

Mann ve ark., (2002), Mn uygulamasının (yaprak veya toprak) iki soya fasulyesi çeşidinin verim ve tohum kalitesi üzerine etkisi değerlendirmişlerdir. Mn'nın toprağa uygulanması veya yapraklara püskürtülmesi, bitki dokusundaki Mn içeriğini ve protein ve yağ içeriğini arttırmıştır. Yapraklara püskürtme uygulamasını toprağa uygulamaktan daha etkili bulmuşlardır.

Irak'ta 2009 y1lında kumlu bir toprakta yürütülen bir tarla denemesinde, yapraktan demir sülfat ve mangan sülfatın farklı dozda 
kombinasyonlarının $(0,50+50,100+100 \mathrm{mg}$ $\mathrm{L}^{-1}$ ), üç soya çeşidinin (LS74, Geza 22 ve Geza 83) verim ve kalitesine etkisi araştırılmıştır. Çalışmayı yürüten Abass ve ark., (2011), $\mathrm{Fe}+$ Mn'nin $50+50 \mathrm{mg} \mathrm{L}^{-1}$ püskürtülmesi uygulamasının, en yüksek bakla bitki ${ }^{-1}(109,4$ bakla), 100 tohum ağırlığı (12,67 gr), tohum verimi $\left(322 \mathrm{~kg} \mathrm{da}^{-1}\right)$ ve tohum protein yüzdesi (\%35) ile sonuçlandığını bildirmiştir. Çeşit $\mathrm{x}$ uygulama interaksiyonu tohum verimi üzerinde etkili bulunmuş ve LS74 çeşidi, $50+50 \mathrm{mg} \mathrm{L}^{-1}$ $\mathrm{Fe}+\mathrm{Mn}$ uygulaması altında en yüksek tohum verimi olan $355 \mathrm{~kg} \mathrm{da}^{-1}$ verim elde edilmiştir.

Gettier ve ark., (1985b) tarafindan V6 (erken; -soyanın altı yapraklı olduğu vejetatif aşama), R1 (geç; -soyada ilk çiçeklenme zamanı) ve hem V6 hem de R1 büyüme aşamalarında yapraktan $112 \mathrm{~g} \mathrm{da}^{-1}$ dozunda Mn uygulamasına soyanın tepkisini belirlemek için üç tarla denemesi yapılmıştır. Determinat tipte olan "Essex" soya çeşidini, "Aeric Ochraquults" ve "Typic Ochraquults" tipi topraklar üzerinde iki farkl toprak tipinde yetiştirmişlerdir. Toprakların Ap horizonda pH 6,3 ila 6,8 arasinda ve Mehlich I ekstrakte edilebilir Mn seviyesi ise 0,8-1,6 mg kg-1 arasında ölçülmüsşür. Yapraktan $\mathrm{MnSO}_{4}$ uygulanmas1, soya verimini kontrole kıyasla 252 $\mathrm{kg} \mathrm{da}^{-1}$ yükseltmiştir. Verim artışlarının kaynăg 1 olarak tohum ağırlı̆̆ ve tohum sayısındaki artış görülmüştür. Kontrol uygulamasında tekli yapraklar, üçlü yapraklar ve tohumlardaki ortalama Mn konsantrasyonları sirasiyla 11,4; 9,3 ve $8,5 \mathrm{mg} \mathrm{kg}^{-1}$ olmuştur. Tohuma aktarılan Mn miktarı, erken dönem yapılan uygulamaya kıyasla geç dönem uygulamasında daha yüksek olmuştur. Geç dönemde yapılan tek uygulamaya kıyasla, erken dönemde yapılan tek uygulamadan daha fazla tohum verimi elde edilmiştir. Bir kez erken dönem $112 \mathrm{~g} \mathrm{da}^{-1}$ Mn dozuna kıyasla, bu dozun hem erken hem de geç dönemde tekrarlandığı uygulamada soya verimi daha yüksek olmuştur. Sonuçta soyada Mn eksikliğinin yapraktan uygulanan Mn ile tam olarak giderilmesi için çoklu yaprak uygulamalarının gerektiği sonucuna varmışlardır.

Alt ve ark., (2018) transgenik yüksek oleik tipte ve normal yă profiline sahip geleneksel tipte soya çeşitlerinde yapraktan $\mathrm{Mn}$ uygulamasının tohum verimi, protein ve yağ oranı ve yağ profili üzerine etkisini tespit etmek için ABD'de Ohio'da deneme yürütmüşlerdir. Uygulama yapılmayan kontrol parselleri ile R3 büyüme döneminde yapraktan yapılan $\mathrm{MnSO}_{4}$ ve Mn-EDTA uygulamalarını karşılaştırmışlardır. 2014 yılında MnSO4 uygulamasiyla birlikte Mn'ca eksik soyalarda verim $14 \mathrm{~kg} \mathrm{da}^{-1}$ artmıştır. $\mathrm{Mn}-\mathrm{SO}_{4}$ aynı zamanda kükürt (S) de tedarik ettiğinden, $\mathrm{S}$ eksikliği tespit edilmemiştir. Diğer üç "lokasyon x yıl"da, soyanın tohumu verimi Mn uygulamasından etkilenmemiştir. Mn uygulamas1, soya tohumunun yağ veya protein içeriğini etkilememiş veya yağ profilini değiştirmemiştir.

Mn gübresinin soya üzerindeki etkisi, Çin'in Sanjiang ovasından alınan Chernozemic çayır toprağının kullanıldı̆̆ 1 bir saksı denemesinde Chen ve ark., (2011) tarafından incelenmiştir. Hefeng 55 soya çeşidine, tohum 1slatma ve yaprağa püskürtme şeklinde, farklı konsantrasyonlarda Mn gübresi uygulamışlardır. 
Mn miktarı, erken dönem yapılan uygulamaya kıyasla geç dönem uygulamasında daha yüksek olmuştur. Geç dönemde yapılan tek uygulamaya kıyasla, erken dönemde yapılan tek uygulamadan daha fazla tohum verimi elde edilmiştir. Bir kez erken dönem $112 \mathrm{~g} \mathrm{da}^{-1}$ Mn dozuna kıyasla, bu dozun hem erken hem de geç dönemde tekrarlandığı uygulamada soya verimi daha yüksek olmuştur. Sonuçta soyada Mn eksikliğinin yapraktan uygulanan Mn ile tam olarak giderilmesi için çoklu yaprak uygulamalarının gerektiği sonucuna varmışlardır.

Alt ve ark., (2018) transgenik yüksek oleik tipte ve normal yă profiline sahip geleneksel tipte soya çeşitlerinde yapraktan Mn uygulamasının tohum verimi, protein ve yă oranı ve yağ profili üzerine etkisini tespit etmek için ABD'de Ohio'da deneme yürütmüşlerdir. Uygulama yapılmayan kontrol parselleri ile R3 büyüme döneminde yapraktan yapılan $\mathrm{MnSO}_{4}$ ve Mn-EDTA uygulamalarını karşılaştırmışlardır. 2014 yılında MnSO4 uygulamasiyla birlikte Mn'ca eksik soyalarda verim $14 \mathrm{~kg} \mathrm{da}^{-1}$ artmıştır. $\mathrm{Mn} \mathrm{SO}_{4}$ aynı zamanda kükürt (S) de tedarik ettiğinden, $\mathrm{S}$ eksikliği tespit edilmemiştir. Diğer üç “lokasyon x yıl”da, soyanın tohumu verimi Mn uygulamasından etkilenmemiştir. Mn uygulaması, soya tohumunun yağ veya protein içeriğini etkilememiş veya yağ profilini değiştirmemiştir.

Mn gübresinin soya üzerindeki etkisi, Çin'in Sanjiang ovasından alınan Chernozemic çayır toprağının kullanıldığı bir saksı denemesinde Chen ve ark., (2011) tarafindan incelenmiștir.
Hefeng 55 soya çeşidine, tohum 1slatma ve yaprağa püskürtme şeklinde, farklı konsantrasyonlarda Mn gübresi uygulamışlardır. Tohum 1slatma ve yaprağa püskürtme uygulamalarında, artan uygulama dozlarıyla birlikte bitki boyu ve ana sap üzerindeki boğum sayısı önce artmış, daha sonra ise azalmıştır. Bitkide dal sayısı, Mn uygulanmayan parsellerde en yüksek olmuştur. Tohum islatma uygulamasinda Mn konsantrasyonundaki artışla birlikte 100 tohum ağırlığı önce artmış sonra azalmış, bitkideki bakla sayısı ise sürekli artmıştır. Yapraktan püskürtme uygulamasında Mn konsantrasyonundaki artışla birlikte 100 tohum ağırlığ 1 sürekli artmış, bitki başına tohum sayısı ise önce artmış sonra azalmıștır. En yüksek tohum verimi, tohumun $0,02 \mathrm{~g} \mathrm{~kg}^{-1} \mathrm{Mn}$ ile kaplanıp, ilave olarak yapraktan $0,87 \mathrm{~g} \mathrm{~kg}^{-1}$ Mn uygulandığı parsellerden elde edilmiştir.

Kobraee ve ark., (2013) tarafindan İran'in Kermanshah bölgesinde 2010 yılında, iki sulama rejimi, iki yapraktan uygulama ve sekiz soya çeşidi içeren bir tarla denemesi yapılmış ve kuraklık stresi koşullarında yapraktan Mn uygulamasının soyanın büyümesi üzerindeki etkisi araştırılmıştır. Bitkilere V4 büyüme aşamasında (4 yapraklı aşama) iki kez \%0,5' lik Mnçözeltisi veya damıtılmış su püskürtmüşlerdir. Sulamalı koşullarda Clark, Williams ve DPX çeşitleri yapraktan Mn uygulamasına en iyi verim yanıtını vermiştir. Su stresi durumunda ise Mn uygulaması, denemede kullanılan bütün çeşitlerde bakla sayısı ve tane verimi üzerine önemli seviyede olumlu etki göstermiştir.

Yapraktan Mn uygulamasına ihtiyaç 
duyulan dönem sıklıkla herbisit uygulamasının zamanlaması ile çakışmaktadır. Heckman ve ark., (1999), mangan sülfatın herbisitler ile aynı tankta karışımının uygulanabilirliğini, Mn eksikliği olan Holmdel kumlu kil (ince ekmekli, karışık, mesic Aquic hapludult) ve Mn açısından yeterli Sassafras kumlu killi (ince killi, silikalı, mesic Typic Hapuldult) toprak koşullarında, ABD, New Jersey'de değerlendirmişlerdir. Mangan sülfatı, V3 büyüme aşamasındaki bitkilerin yapraklarına, 0, 0,5 ve 2.,0 lb Mn acre $^{-1}$ dozunda tek başına veya acifluofen, chlorimuron ethyl, imazethapyr, ve bentazon ile tankta karıştırdıktan sonra uygulamışlardır. Denemede IV. Olum Grubu'ndan iki soya çeşidi kullanmışlardır. Mangan sülfatın tek başına veya herbisitle karışım halinde kullanılması, bitkilerdeki Mn eksikliğini giderme üzerine olan etkinliğini değiştirmemiştir. 2,0 lb Mn acre1 oranı bitki dokusundaki Mn miktarını daha etkili bir şekilde arttırmış ve Mn eksikliğini 0,5 lb $\mathrm{Mn}$ acre $^{-1}$ oranından farklı olarak tamamen ortadan kaldırmıştır. Sonuç olarak herbisitlerle mangan sülfatın karıştırılıp uygulanmasının soyada herhangi bir zarar oluşturmayıp yabancı ot kontrolünü etkilemediğini tespit etmişlerdir.

Parker, (2016) tarafindan 2014 ve 2015 yıllarında, yapraktan uygulanan iki farklı mangan ürününün, glyphosate'a dirençli soyalardaki sararma etkisini ortadan kaldırmak için Mn ve glyphosate ürünlerinin karıștırılarak uygulandığı bir çalışma yapılmıştır. Bitki Mn konsantrasyonundaki en büyük artış, yapraktan Mn uygulamasının glifosat uygulamasından 24 saat önce yapıldığında elde edilmiştir. Her iki Mn formülünün uygulanması da bitki Mn konsantrasyonunu arttırsa da, toplam biyokütle, bitki klorofil veya nihai verim üzerinde tutarlı bir etkiye neden olmamıştır; ancak, görsel gözlemlerin yanı sıra klorofil ölçümleri, her iki yılda da sararma görülmediğini ortaya ç1karmıştır.

Basso ve ark., (2011), yürüttükleri çalışmada, Glyphosate herbisitine toleranslı soyaya yapraktan bitkiler V5 aşamasında iken $720 \mathrm{~g} \mathrm{~L}^{-1}$ i.e dozunda ve \%14 ( $\left.\mathrm{m} \mathrm{v}^{-1}\right)$ konsantrasyonunda Mn 0,2 L $\mathrm{da}^{-1}$ dozunda uygulamışlardır. Glyphosate uygulaması soyada Mn ve azotun emilim ve yapraktaki miktarını etkilememiştir. Yapraklardaki Mn miktarındaki artışa karşılık soya veriminde artış görülmemiştir. Bu durum, Mn seviyesinin yeterli olduğu topraklarda, glyphosate herbisitine toleranslı genetiği değiştirilmiş soya kullanılması durumunda yapraktan Mn ilavesinin gerekli olmadığını göstermiştir.

Nava ve ark., (2015), "Roundup ready" soyada Mn kullanımının verim ve yapraktaki Mn miktarına etkisi konusunda bir çalışma yürütmüşlerdir. İki farklı büyüme aşamasında (V4 ve V6), beş farklı doz Mn (0, 5,7, 11,4, 17,0 ve $22,7 \mathrm{~g} \mathrm{da}^{-1}$ ) yapraktan kullanılmıştır. Mn ve herbisit birlikte ve iki kez uygulanmıştır. Uygulamalar sadece yapraktaki Mn miktarını artırmış, verim ve verim komponentlerini değiştirmemiştir. 


\section{Manganın Farklı Besin Elementleriyle Bir-} likte Yapraktan Kullanımı

Fe veya $\mathrm{Mn}$ besin elementlerinin birinin yüksek seviyelerde uygulanması genellikle diğeri için nispeten düşük alım seviyelerine sebep olur. Bu besin elementlerinin antagonistik ilişkisi ya kökler tarafından emilim sırasında ya da köklerden toprak üstü aksama aktarımda ortaya çıkabilir. Moosavi ve Ronaghi (2011) tarafindan, Fe ve Mn'nin toprak ve yaprak uygulamalarının soya bitkisinin verim ve FeMn durumuna etkisini incelemek için bir sera çalışması yapılmıştır. Sonuçlar, Fe veya Mn'nin toprak veya yaprak uygulamasının soya kökünün veya toprak üstü aksamının kuru madde verimini etkilemediğini göstermiştir. Fe'nin hem toprak hem de yaprak uygulamaları toprak üstü aksamın Fe konsantrasyonu ve alımını önemli ölçüde artmıştır ancak yaprak uygulaması daha etkili bulunmuştur. Yapraktan uygulanan \%1'lik demir sülfat, bitkinin Fe içeriğini artırmış fakat toprak üstü aksamının kuru madde verimini veya $\mathrm{Mn}$ konsantrasyonu üzerinde bir etkisi olmamıştır. Fe'nin topraktan uygulanmas1, muhtemelen Fe'nin Mn absorpsiyonu üzerine bilinen antagonistik etkisine bağlı olarak, köklerin Mn konsantrasyonunu/alımını azaltmıştır. Topraktan Fe uygulanmasına toprak üstü bitki aksamında Mn düzeyinin düşme durumu köklerdekinden daha fazla olmuştur. Bu nedenle, köklerce Mn emiliminin azalması ve toprak üstü aksama aktarımı, Fe`nin Mn beslenmesi üzerindeki etkisini bastırmanın ana nedenleri olmuştur. Ayrıca, topraktan uygulanan yüksek düzeyde Mn (30 mg $\mathrm{kg}^{-1} \mathrm{Mn}$ ), kökten toprak üstü aksama doğru Fe aktarımını azaltmıştır. Sonuç olarak, kireçli topraklarda yetişen soyada verim düşüşünü ve besin dengesizliğini önlemek için yapraktan Fe-Mn uygulamalarının uygun olduğu tespit edilmiştir.

Irak’ta, çeşit seçimi ve yapraktan Mn ve Zn uygulamalarının soyada bazı büyüme özelliklerine etkisini belirlemek amaciyla Hameed ve ark., (2019) tarafından 2013 yılında iki farklı bölgede tarla denemeleri yapılmıştır. Üç soya çeşidi (Industrial/2, Iman ve Shaima), üç konsantrasyonda Mn yaprak gübresi uygulamas1 (0, 75 ve $100 \mathrm{mg} \mathrm{MnS} 04 . \mathrm{H} 20 \mathrm{mg}$ $\left.\mathrm{L}^{-1}\right)$ ve üç konsantrasyonda $\mathrm{Zn}(0,50$ ve $75 \mathrm{mg}$ ZnS04.7H20 mg L-1) püskürtülmüştür. Sonuçlar, her iki bölge için Iman çeşidinin bitki boyu ve ilk bakla yüksekliği üzerinde üç faktörün etkileşiminin üstün olduğunu göstermiştir. İki faktör kombinasyonu için, 75 ve $100 \mathrm{mg} \mathrm{L}^{-1} \mathrm{Mn}$ konsantrasyonu seviyesinin, $75 \mathrm{mg} \mathrm{L}^{-1} \mathrm{Zn}$ ile uygulandığında her iki deneme bölgesinde de üstün bulunmuştur.

\section{Yapraktan Mangan Püskürtmenin Soyada Hastalıklara Etkisi}

Soya kök ve sapında ortaya çıkan toprak kaynaklı patojenlerin neden olduğu kök çürüklüğü ve sap çürüklügü hastalıkları soya tarlalarında yaygın olarak bulunan hastalıklar olup önemli düzeyde verim kayılarına neden olmaktadirlar. Fusarium virguliforme, F. tucumaniae, Sclerotinia sclerotiorum ve Macrophomina phaseolina misellerinin, farklı konsantrasyonlarda suda seyreltik $(0,25,37,5$, $50,100,200,300,400,500,800$ ve $100 \mathrm{ug} \mathrm{mL}^{-}$ $\left.{ }^{1}\right)$ mangan fosfite (MnPhi) duyarlığ 1 , patates 
dextrose agar media üzerinde değerlendirilmiştir. Misel büyüme duyarlılığı, logaritmik lineer regresyon analizi kullanılarak, Carmona ve ark., (2017) tarafından tespit edilmiştir. Misel büyümesinin \%50'sini engellemek için gereken MnPhi konsantrasyonu (IC50) en düşük (105 $\mu \mathrm{g}$ $\left.\mathrm{ml}^{-1}\right)$ Fusarium spp'de, en yüksek $\left(409 \mu \mathrm{g} \mathrm{ml}^{-1}\right)$ M. Phaseolina'da elde edilmiştir. Sklerotinya, $500 \mu \mathrm{g} \mathrm{ml}^{-1}$ 'de tamamen engellenmiştir. $\mathrm{Bu}$ çalışma, toprak kaynaklı mantarların neden olduğu hastalıklara karşı MnPhi'nin direkt in vitro fungisit / fungistatik etkisine ilişkin ilk rapor olmuştur.

Sclerotinia sclerotiorum'un neden olduğu beyaz küfün soya verimini düşürmedeki önemi göz önünde bulundurarak, hastalık kontrolü için, De Novaes, (2016) tarafindan yeni alternatifler araştırılmıştır. Mn-fosfitinin, soya bitkilerinin S. sclerotiorum ile mücadelesine katkısını belirlemek amaciyla bitkilerdeki fotosentetik performans, savunma enzimlerinin durumu, antioksidan metabolizması, hidrojen peroksit ve malondialdehit (MDA) konsantrasyonlarını araştırmıştır. Beyaz küf şiddeti, Mn-fosfit püskürtülen bitkilerde önemli ölçüde azalmış ve bu, yaprak gazı değişimi ve Chl a floresan parametrelerine yansımıştır. Hastalıkla inoküle edilmiş bitkilerde, Mn-fosfit püskürtmesi yapılmayan bitkilere kıyasla, püskürtme yapılmış bitkilerde, SOD (superoxide dismutase), catalase, peroxidase ve ascorbate peroxidase aktiviteleri artmıştır. Hastalıkla aşılanmış bitkilerde GLU ( $\beta$-1,3- glucanases) ve PAL (phenylalanine ammonia-lyase) aktiviteleri, Mn fosfit püskürtülenlerde daha yüksek olmuş ve beyaz küf şiddetini azaltmaya katkıda bulunmuştur. Sonuç olarak, bu çalışma Mn fosfitinin beyaz küfü kontrol etme potansiyelinin hem biyokimyasal hem de fizyolojik seviyelerde yeni kanıtlarını ortaya koymuştur.

Novaes ve ark., (2019), fotosentetik performans, kitinaz (CHI), GLU, PAL ve polyphenol oxidase (PPO) gibi savunma enzimlerinin ve antioksidan metabolizması ile ilişkili olan SOD, katalaz, peroksidaz (POX) ve askorbat peroksidaz (APX) yanında hidrojen peroksit (H202), süperoksit (O2) ve malondialdehit (MDA) aktivitelerini inceleyerek, fluazinam fungusiti ve Mn-fosfitin soya bitkilerini $S$. sclerotiorum enfeksiyonuna karşı korunmadaki potansiyelini araştırmışlardır. Beyazküfgelişimi fluazinam tarafindan tamamen engellenmiştir. Soya metabolizması fluazinam uygulaması ile değişmemiştir. Beyaz küf şiddeti, Mn fosfit püskürtülen bitkilerde, püskürtülmeyen bitkilerden daha iyi bir fotosentetik performans sergilemiştir. S. sclerotiorum'un misel büyümesi $\mathrm{Mn}$ fosfit tarafından engellenmiştir. Katalaz, peroksidaz ve SOD aktiviteleri azalırken, CHI, GLU ve PAL aktiviteleri, püskürmeyen bitkilere kıyasla Mn fosfitle püskürtülen bitkiler için 96 saat sonra artmıştır. Sonuç olarak soya yapraklarındaki etki mekanizmasından dolayı Mn-fosfit beyaz küf oluşumunu ve patojene bağlı fizyolojik bozuklukları etkilemiştir.

Soya bitkileri, Rhizoctonia, Fusarium, Sclerotium, Collectotrichum, Alternaria ve Macrophomina türlerine ait bitki patojenik mantarları tarafından sıklıkla enfekte edilir. Dhobleve Kulkarni,(2016) tarafından,sözkonusu mantarlar üzerinde bazı metal nanoparçacıkların 
- Çinko (ZnNP'ler) ve Manganez (MnNP'ler) - antifungisidal özelliklerini 25, 50, 75 ve 100 ppm konsantrasyonlarında tespit için denemeler yürütülmüştür. Rhizoctonia solani, Fusarium oxysporum, Sclerotium rolfsii, Collectotrichum truncatum,Alternariaalternate ve Macrophomina phaseolina, her iki nanopartikül ile patates dekstroz agarı üzerinde, gıda zehirleme tekniği (food poisoning technique) yoluyla muamele edilmiştir. Sonuçta, her iki nanopartikül de, çeşitli düzeylerde, bu bitki patojenlerine karşı antifungal özelliklere sahip bulunmuştur. Her iki nanopartikülün 100 ppm konsantrasyonuyla muamele edilerek mantarların çoğunun en üst düzeyde engellendiğini göstermişlerdir. Sonuçlar ayrıca, bitki nanoparçacıklarının konsantrasyonunun artmayla bitki patojenik mantarlarının engellenmesinin arttığını göstermişlerdir. İnsanlarda yüksek toksisite gösteren sentetik fungusitler yerine, ZnNP ve MnNP'lerin soya bitkilerini korumak için bitki fitopatojenik mantarlarına karşı etkili bir şekilde kullanılabileceği sonucuna varmışlardır.

Manganın bitkilerde mantarlara karşı oluşturduğu direnç lignifikasyon veya doğrudan engelleme ile ilişkili olabilir. Geleneksel soya çeşitleri ve bunların glifosata dayanıklı transgenik türevlerinin (RR) kullanıldığ ve lignin seviyelerinin mantarların ortaya çıkışına ve Mn'ın yaprak uygulamasındaki değerlendirilmesi amaciyla Brezilya' da Carvalho ve ark., (2015) bir deneme yürütmüştür. İkisi konvansiyonel, ikisi bu çeşitleri RR türevleri (BRS Celeste ve BRS Baliza RR; BRSGO Jataí ve BRS Silvânia RR) olacak şekilde toplam dört soya çeşidi, dört farklı dozda yapraktan Mn dozuna $(0,20,40$ ve $60 \mathrm{~g}$ Mn da-1), iki büyüme aşamasında ( R1 ve R3) maruz bırakılmıştır. Tohumları depolanmadan önce ve altı ay depolamadan sonra bir sağllk testine (Blotter testi) tabi tutmuşlardır. Tohumdaki Mn ve tohum kabuğundaki lignin seviyelerini belirlemişlerdir. Yapraktan Mn uygulamasının, hasat edilen soya tohumlarında Cercospora kikuchii, Fusarium spp.ve Aspergillus spp. görülme sıklığını düşürdüğünü tespit etmişlerdir. Soya bitkilerine hem R1 hem de R3 aşamalarında yapraktan uygulanan Mn'nin tohumlara taşındığını ancak tohum kabuğunda lignin üretimini etkilemediğini bildirmişlerdir.

\section{Sonuçlar}

Ülkemizde mangan eksikliği, danelik soya ekiminin yaygın olduğu Çukurova ve silajlık soya ekiminin yaygın olduğu Orta Anadolu'da yaygındır. Mangan eksikliğinin en yaygın olduğu üçüncü alan olan Güneydoğu Anadolu Bölgesi, gerek iklim gerekse de yeni sulama alanlarının devreye alınıyor olması sebebiyle, ana ürün koşullarında mısır ile rekabette zorlanan fakat ikinci ürün koşullarında üstünlüğü Çukurova koşullarında ispatlanmış olan soyada, potansiyel bir gelişme alanı durumundadır.

Soya bitkisinin mangan eksikliğine çok hassas bir tür olması, soyada diğer mikrobesin elementlerinden daha yüksek sıklıkta görülüyor olması, mangan eksikliğinin biyolojik azot bağlamayı ve verimi (dane ve biyokütle) düşürüyor olması durumu kolaylıkla üstesinden gelinebilecek bir sorundur. Çünkü eksiklik durumunda soya, mangan gübrelerine iyi yanıt 
vermektedir ve ileri ülkelerde soyada mangan kullanımı yaygındır. Benzer bir element olan magnezyum noksanlığı önce yaşlı yapraklarda görülmesine karşın mangan noksanlığı genç yapraklarda damarlar arasında sararma şeklinde belirti göstermektedir. $\mathrm{Mn}, \mathrm{Zn}, \mathrm{Cu}$ ve Fe eksikliğinin erken görsel semptomlarının yorumlanması genellikle zordur ve yanlış teşhisler yaygındır. Gözle görülür belirtiler göstermeden eksiklik olabilmesi nedeniyle de soya tarımıyla uğraşan çiftçilerin bir tarlada,uzun yılları temsilen en az bir kez soya bitkisinde, teşhiste en doğru sonuç veren metod olan yaprak teşhisiyle durum analizi fayda sağlayacaktır. Yaprak analizleri doğru teşhis için en doğru araçtır ki yaprakta 25-30 ppm'den düşük olması durumunda bitkide mangan eksikliği muhtemeldir. Yaprakta mangan seviyesi için alt kritik değer yaklaşık 17 ppm'dir. Tam çiçeklenme döneminde en üstteki olgun üç yaprak, toprağının Mn durumunun tespiti için yapılacak kimyasal analizde kullanmak amacıyla örneklemede bitkinin uygun bir parçasıdır. Diğer besin elementlerinin durumunun da tahlil ettirilmesi ve eksiklik durumunda gübreleme yapılması verim artışları sağlama potansiyeli taşımaktadır.

Ülkemiz topraklarının çoğunun kireçli olduğu düşünüldüğünde manganın topraktan kullanımı etkisizlik, maliyet ve rizosfer kirliliği gibi risklere sahiptir. Topraktan uygulamalar, diğer besin elementleri ile olumsuz etkileşim potansiyeli nedeniyledemanganuygulamalarındadezavantaj oluşturmaktadır. Yapraktan uygulamalar ise hem gereken mangan gübresi miktarını azaltma ve antagonistik olumsuzluklardan kaçınma avantajı sağlamakta hem de eksikliği durumunda verim artırıcı etkiler yapmaktadır. Yapraktan mangan uygulamaları konusunda yapılmış çalışmalar incelenince bu uygulamalarda olumsuz etki ortaya çıkmadığ1, olumlu veya nötr etkiler gözlemlendiği görülmektedir. Nötr etkinin görüldüğü manganca eksik koşullarda yürütülen çalışmalarda ölçülen fizyolojik parametrelerde iyileşmeye rağmen bunun verime yansımaması durumu, yapılmış çalışmalarda muhtemel bir ikincil ve üçüncül mikrobesin elementi stresinin (eksiklik veya fazlalık) bulunma durumunu düşündürmektedir. Bu çalışmalarda diğer besin elementlerinin eksikliğinin ölçülmemiş olması bir eksiklik olarak görülmüştür. Ülkemizde yapılacak çalışmalarda çoklu besin elementi stresinin(fazlalık/eksiklik) de araştırılacak şekilde denemeler kurulması önem arz etmektedir. $\mathrm{Bu}$ durum özellikle denemelerde mangan eksikliğini garanti altına almak için tercih edilebilecek kumlu topraklar için geçerlidir.

MnSO4 uygulamalar1 EDTA-Mn'a kıyasla düşük maliyet, daha yüksek etkinlik avantajı yanında bitkilere kükürt elementi de sağlama avantajına sahiptir ve yapraktan uygulamaları başarılıdır. $\mathrm{Bu}$ nedenle dünyada yapraktan mangan uygulamaları için genelde mangan sülfat tercih edilmektedir. Manganın bitkilerde hareketi iyi olmadığından uygulama 2-3 kez tekrarlanmalıdır ki ilk uygulamanın erken vejetatif aşamada yapılması faydayı artırmaktadır. Hem erken (V4-V6 / dört-altı yapraklı aşama) hem de geç dönemde (R1ilk çiçeklerin görüldüğü aşama) tekrarlandığg uygulamalarda soya veriminin daha yüksek 
olduğu raporlanmıştır. Soyada ruhsatlı yaygın herbisitlerle mangan sülfatın karıştırılıp uygulanmasının soyada bir zarar oluşturduğu rapor edilmemiştir.

Soyada yürütülmüşs yeni çalışmalarda, yapraktan uygulanan yenilikçi ürünler olan mangan fosfite (MnPhi) veya mangan nanoparçacıkların (MnNP'ler) soyada fungusitlerle benzer etkiler gösterdiği ve hastalık azaltıcı etkiler sağladığı tespit edilmiştir. Gelişme potansiyeli barındıran bu yeni araştırma alanı, insan ve çevre sağlığına yüksek zararlar gösteren pestisitlere olan alternatif ürün arayışlarının çift etkili bir neferi olma potansiyeline sahiptir.

\section{Kaynaklar}

Abass, J. M., Serhan, I. A., and Mutlag, N. A. (2011). Effect of leaf nutrition by iron and manganese in yield and quality of three soybean cultivars. Diyala Agricultural Sciences Journal, 3(1).

Adams, M. L., Norvell, W. A., Philpot, W. D., and Peverly, J. H. (2000). Toward the discrimination of manganese, zinc, copper, and iron deficiency in 'Bragg'soybean using spectral detection methods. Agronomy Journal, 92(2), 268-274.

Alt, D., Ng, S. J., Grusenmeyer, J., and Lindsey, L. E. (2018). Seed Yield and Quality of Transgenic High-Oleic and Conventional Soybean as Influenced by Foliar Manganese Application. Crop Science, 58(2), 874-879.

Basso, C. J., Santi, A. L., Lamego, F. P., and Girotto, E. (2011). Foliar application of manganese in transgenic soybean tolerant to glyphosate. Ciência Rural, 41(10), 1726-1731.

Burnell, J. N. (1988). The biochemistry of manganese in plants. In Manganese in soils and plants (pp. 125-137). Springer, Dordrecht.

Campbell, L. C., and Nable, R. O. (1988). Physiological functions of manganese in plants. In Manganese in soils and plants (pp. 139-154). Springer, Dordrecht.

Carmona, M. A., Simonetti, E., Ravotti, M. E., Scandiani, M., Luque, A. G., Formento, N. A., and Sautua, F. J. (2017). In vitro antifungal/fungistatic activity of manganese phosphite against soybean soilborne pathogens. Phyton, International Journal of Experimental Botany, 86, 265269.

Carvalho, E. R., Oliveira, J. A., Reis, L. V., and Ferreira, T. F. (2015). Foliar manganese in 
the health and lignin quality of conventional and glyphosateresistant soybean seeds. Revista Ciência Agronômica, 46(1), 135 143.

Chen, D., Zhao, H., Wang, Q., Wu, L. L., Li, C. S., Yu, H., and Zhang, Y. X. (2011). Effects of seed-coat and foliar-applied manganese on agronomic traits and yield of soybean. Soybean Science, 30(5), 880-882.

De Novaes, M. I. C. (2016). Physiological and Biochemical Aspects of Soybean Sprayed with Manganese Phosphite for the White Mold Control (Doctoral dissertation, Universidade Federal de Viçosa).

Dhoble, S. M., and Kulkarni, N. S., 2016. Antimycotic activity of zinc and manganese nanoparticles on commercially important phytopathogens of soybean (Glycine max (L.) Merril). , Sch. Acad. J. Biosci.,4(11):1032-1037.

Diedrick, K., 2010. Manganese fertility in soybean production. Crop Insights. Pioneer Hi-Bred Int., Inc., Johnston, IA.[Online] https:/www. pioneer. com/home/site/us/ agronomy/library/template. CONTENT/ guid. 6693CDF7-8169-DE29-F6B252A7C87A6E80.

Gettier, S. W., Martens, D. C., and Brumback, T. B., 1985b. Timing of Foliar Manganese Application for Correction of Manganese Deficiency in Soybean 1. Agronomy journal, 77(4), 627-630.

Gettier, S. W., Martens, D. C., and Donohue, S. J., 1985a. Soybean Yield Response Prediction from Soil Test and Tissue Manganese Levels 1. Agronomy journal, 77(1), 63-67.

Ghasemi Fasaei, R., Ronaghi, A., Maftoun, M., Karimian, N., and Soltanpour, P. N., 2002. Influence of FeEDDHA on iron-manganese interaction in soybean genotypes in a calcareous soil. Journal of plant nutrition, 26(9), 1815-1823.

Ghazali, N. J.,and Cox, F. R., 1981. Effect of Temperature on Soybean Growth and Manganese Accumulation 1. Agronomy Journal, 73(2), 363-367.

Graham, M. J., Nickell, C. D., and Hoeft, R. G., 1995. Inheritance of tolerance to manganese deficiency in soybean. Crop science, 35(4), 1007-1010.

Hameed, H. M., Shaker, A. T., and Ali, K. A. A., 2019. Effect of Manganese and Zinc Foliar Application on Growth and Yield of Some Soybean Varieties Glycine max (L.) Merrill. Tikrit Journal for Agricultural Sciences. Mağallä̈ Tikrīt li-l-'ulūm alzirā'at, 16(3), 14-27.

Heckman, J. R., Majek, B. A., and Prostko, E. P., 1999. Application of manganese fertilizer with postemergence soybean herbicides. Journal of production agriculture, 12(3), 445-448.

Izaguirre-Mayoral, M. L., and Sinclair, T. R., 2005. Variation in manganese and iron accumulation among soybean genotypes growing on hydroponic solutions of differing manganese and nitrate concentrations. Journal of plant nutrition, 28(3), 521-535.

Johansson, J., 2005. Manganese solubility due to compaction in soils under corn and soybean. SLU, Dept. of Soil Sciences, Uppsala.

Kluthcouski, J., and Nelson, L. E., 1979. Variations in the manganese concentrations in soybean trifoliolates. Communications in Soil Science and Plant Analysis, 10(10), 1299-1310.

Kobraee, S., Shamsi, K., and Saeed, V. M., 2013. Soybean growth under drought stress and foliar manganese. International Journal of Biosciences (IJB), 3(2), 122-131. 
Mann, E. N., Resende, P. M. D., Mann, R. S., Carvalho, J. G. D., and Von Pinho, É. V. D. R., 2002. Effect of manganese application on yield and seed quality of soybean. Pesquisa Agropecuaria Brasileira, 37(12), 1757-1764.

Mascagni, H. J., and Cox, F. R., 1985. Calibration of a Manganese Availability Index for Soybean Soil Test Data 1. Soil Science Society of America Journal, 49(2), 382386.

Masuda, T., and Goldsmith, P. D., 2009. World soybean production: area harvested, yield, and long-term projections. International food and agribusiness management review, 12(1030-2016-82753), 1-20.

Mederski, H. J., and Hoff, D. J., 1958. Factors Affecting Absorption of Foliar-Applied Manganese by Soybean Plants 1 . Agronomy Journal, 50(4), 175-178.

Millaleo, R., Reyes-Díaz, M., Ivanov, A. G., Mora, M. L., and Alberdi, M., 2010. Manganese as essential and toxic element for plants: transport, accumulation and resistance mechanisms. Journal of soil science and plant nutrition, 10(4), 470481.

Moosavi, A. A., and Ronaghi, A., 2011. Influence of foliar and soil applications of iron and manganese on soybean dry matter yield and iron-manganese relationship in a Calcareous soil. Australian Journal of Crop Science, 5(12), 1550.

Mukhopadhyay, M. J., and Sharma, A., 1991. Manganese in cell metabolism of higher plants. The Botanical Review, 57(2), 117149.

Nava, I. A., Gonçalves Jr, A. C., Schwantes, D., Coelho, G. F., Stangarlin, J. R., and Leismann, E.A. V., 2015. Foliar application rates of manganese in phenological stages of roundup ready soybean. Spanish Journal of Rural Development, 6, 3-4.

Novaes, M. I. C., Debona, D., FagundesNacarath, I. R. F., Brás, V. V., and Rodrigues, F. A., 2019. Physiological and biochemical responses of soybean to white mold affected by manganese phosphite and fluazinam. Acta Physiologiae Plantarum, 41(12), 186.

Ohki, K., 1981. Manganese critical levels for soybean growth and physiological processes. Journal of plant nutrition, 3(14), 271-284.

Parker, K. E., 2016. Agronomic management of soybean with foliar manganese and apical meristem alterations (Doctoral dissertation).

Purcell, L. C., King, C. A., and Ball, R. A., 2000. Soybean cultivar differences in ureides and the relationship to drought tolerant nitrogen fixation and manganese nutrition. Crop Science, 40(4), 1062-1070.

Reddy, K. R., Saxena, M. C., and Pal, U. R., 1978. Effect of iron and manganese on 65 $\mathrm{Zn}$ absorption and translocation in soybean seedlings. Plant and soil, 49(2), 409-415.

Santos, E. F., Santini, J. M. K., Paixão, A. P., Júnior, E. F., Lavres, J., Campos, M., and dos Reis, A. R., 2017. Physiological highlights of manganese toxicity symptoms in soybean plants: Mn toxicity responses. Plant physiology and biochemistry, 113, 6-19.

Singh, K., and Banerjee, N. K., 1984. Soybean yield and manganese content as affected by rates of manganese. Legume Research, 7(1):17-22.

Socha, A. L., and Guerinot, M. L., 2014. Mneuvering manganese: the role of transporter gene family members in manganese uptake and mobilization in plants. Frontiers in Plant Science, 5, 106. 
Sönmez, B., Özbahçe, A., Akgül, S., ve Keçeci, M., 2018. "Türkiye topraklarının bazı verimlilik ve organik karbon (TOK) içeriğinin coğrafi veritabanının oluşturulması". Proje Sonuç Raporu (TAGEM/TSKAD/11/A13/P03). Toprak Gübre ve Su Kaynakları Merkez Araştırma Enstitüsü. Tarımsal Araştırmalar ve Politikalar Genel Müdürlüğü, Ankara.

TÜİK., 2018. Bitkisel üretim istatistikleri. http:// www.tuik.gov.tr/PreTablo.do?alt_id=1001 (Erişim tarihi: 19.11.2019).

Weiland, R. T., Noble, R. D., and Crang, R. E., 1975. Photosynthetic and chloroplast ultrastructural consequences of manganese deficiency in soybean. American Journal of Botany, 62(5), 501-508.

Wilson, D. O., Boswell, F. C., Ohki, K., Parker, M. B., Shuman, L. M., and Jellum, M. D., 1982. Changes in Soybean Seed Oil and Protein as Influenced by Manganese Nutrition 1. Crop Science, 22(5), 948-952.

Zhang, Y., 2005. Effect of manganese on yield in different soybean genetic types. Chinese agricultural science bulletin, 21(7), 245247. 